\title{
Chinese Foreign Exchange Reserves and the U.S. Economy
}

\author{
Christopher Neely, Assistant Vice President and Economist
}

T he Chinese government has the largest foreign exchange reserves in the world, which are assets (usually bonds) held by a central bank or other government agency that are liabilities of some foreign entity. As the figure shows, the value of Chinese foreign exchange reserves peaked at just over $\$ 4$ trillion in June 2014 and has since declined to $\$ 3.23$ trillion (as of January 2016). ${ }^{1}$ About 60 percent of Chinese foreign exchange reserves are believed to be held in dollar-denominated assets-mostly U.S. Treasury securities but also many agency and corporate bonds-although the exact composition of the reserves is confidential. The reserves provide the Chinese government with valuable credibility, financial flexibility, and the ability to respond to emergencies.

China has accumulated these assets because the Chinese sell many more goods and services abroad than they purchase. That is, China has run a large current account surplus. The proceeds from this surplus have gone (indirectly) into the purchase of foreign exchange reserves. China has sold more goods and services abroad than it has purchased because it has a very high domestic savings rate that reduces its consumption of imports.

\section{China's very substantial foreign exchange reserves have declined precipitously and the Chinese policy corrections may impact the U.S. economy.}

Since June 2014, however, Chinese foreign exchange reserves have been declining because Chinese residents are essentially purchasing foreign assets from the government with their domestic assets, reducing the Chinese foreign exchange reserves. That is, the People's Bank of China (PBC, the central bank) is indirectly selling some of its foreign assets to domestic residents who wish to diversify their portfolios as the Chinese economy slows and domestic real estate remains very highly priced.

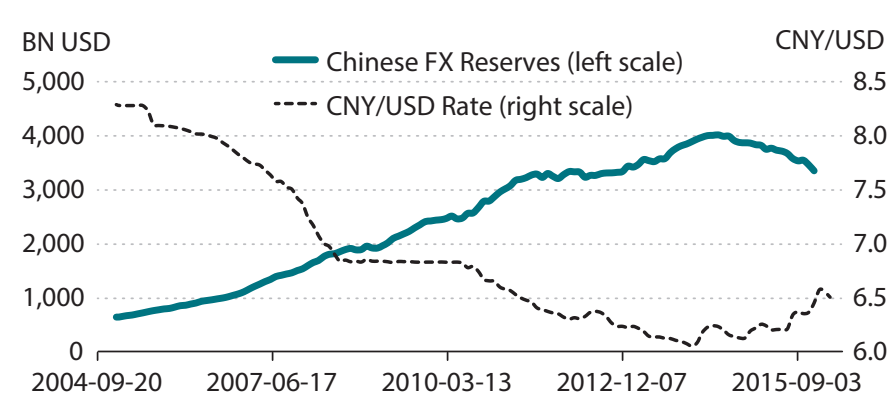

NOTE: BN USD, billions of U.S. dollars; CNY/USD, ratio of Chinese yuan to U.S. dollars; $F X$, foreign exchange.

SOURCE: Federal Reserve Economic Database (FRED ${ }^{\circledR}$ ), Federal Reserve Bank of St. Louis, https://research.stlouisfed.org/fred2/series/TRESEGCNM052N; accessed April 12, 2016.

Domestic purchases of foreign assets are called capital outflows. Although China has very substantial reserves, continued outflows will reduce reserves below desired levels and eventually the authorities may have to choose some combination of policies to stem these outflows. How could China respond to continued capital outflows, and how could these choices affect the U.S. economy?

First, the Chinese authorities could slow or halt capital outflows by further restricting purchases of foreign assets by Chinese residents. Like many emerging market economies, China has long maintained a closely managed exchange rate and a highly regulated financial system, including capital controls - that is, regulations on international purchases and sales of assets. The Chinese government regulates both domestic purchases of foreign assets and foreign purchases of domestic assets. For example, Chinese firms must sell any foreign currency earnings at state-owned banks, and purchases of foreign currency by domestic firms and residents are restricted, although individuals are still permitted to move up to $\$ 50,000$ per year in foreign assets. The purpose of these capital controls is to reduce the volatility of such flows (for stability) and to skew the flows toward foreign direct investment (FDI), which is seen as being stable and encouraging technology 
transfer. Expansion of such controls would have no particular effect on the U.S. economy, but it would run counter to the longer-run goal of the Chinese authorities to reduce their financial regulation and increase the international use of the Chinese currency (CNY).

Second, the Chinese authorities could reduce or even reverse outflows by tightening monetary policy with some combination of increased reserve requirements or higher domestic interest rates. In recent years, the PBC has moved away from regulatory tools such as directly changing reserve requirements and toward market-based measures such as influencing interest rates, although it still does use changes in reserve requirements. Higher domestic interest rates would make Chinese bonds relatively more attractive and thereby reduce purchases of foreign assets. But such a tightening would have the very undesirable side effect of slowing domestic growth. Such a policy would have little direct effect on the United States, though.

Third, Chinese authorities could devalue the CNY substantially against a basket of foreign currencies, including the dollar. This tactic would reduce domestic purchases of foreign assets by making them more expensive. On the other hand, anticipations of such a devaluation would increase the desire to purchase foreign assets before the devaluation, substantially increasing the rate at which the authorities must sell foreign exchange reserves. Such a devaluation would make Chinese goods less expensive relative to foreign goods, thereby making U.S. industries less competitive with their Chinese counterparts.
Finally, the Chinese authorities could defer a decision on policy changes by continuing to sell off their foreign exchange reserves to domestic residents. Some analysts have expressed concern that sales of a very large amount of Chinese foreign exchange reserves could raise U.S. interest rates across the yield curve. But if the sales merely reflect a transfer of assets from Chinese authorities to Chinese residents, one must wonder if they will have any effect at all. In addition, rapid sales that raise U.S. bond yields significantly would also reduce the value of the Chinese portfolio, making it an unpalatable strategy for the Chinese authorities.

\section{Note}

1 See "China's Foreign-Exchange Reserves Decline to $\$ 3.23$ Trillion." Bloomberg News, February 6, 2016; http://www.bloomberg.com/news/articles/2016-0207/china-s-foreign-exchange-reserves-decline-to-3-23-trillion. 